\title{
Hydrogeomorphology, NDWI and, NDVI of the Meghadrigedda Sub-Watersheds for Optimal Utilization of Resources, Visakhapatnam District, Andhra Pradesh-India Using Landsat Data 2000 and sentinel Data 2020
}

\author{
Usha Chirala, Bhavana Pedada \\ Department of Geo-Engineering, Andhra University, Vishakhapatnam, India \\ Email: u_chirala@yahoo.com, bhavanap1997@gmail.com
}

How to cite this paper: Chirala, U. and Pedada, B. (2021) Hydrogeomorphology, NDWI and, NDVI of the Meghadrigedda Sub-Watersheds for Optimal Utilization of Resources, Visakhapatnam District, Andhra Pradesh-India Using Landsat Data 2000 and sentinel Data 2020. International Journal of Geosciences, 12, 584-604.

https://doi.org/10.4236/ijg.2021.126033

Received: April 16, 2021

Accepted: June 27, 2021

Published: June 30, 2021

Copyright $\odot 2021$ by author(s) and Scientific Research Publishing Inc. This work is licensed under the Creative Commons Attribution International License (CC BY 4.0).

http://creativecommons.org/licenses/by/4.0/

\begin{abstract}
With global warming and over-exploitation of water resources due to population explosion and related issues, numerous studies are being carried around the world in an effort to reinstate a state of a balanced life between the existing water resources and their utilization by human beings. Keeping in view, a watershed of 366 sq.km on 1:50,000 scale $65 \mathrm{O} / 1$ SOI map surrounding the Meghadrigedda reservoir in Visakhapatnam district of Andhra Pradesh, India has been taken up for the study. The watershed has been delineated into nine sub-watersheds and hydrogeomorphology, drainage, drainage density, slope, NDVI and NDWI of the study area has been carried out using Landsat data 2010 and Sentinel data 2020 in ARCGIS 10.0 environment. All the villages in the catchment greatly depend on groundwater for irrigation, drinking as well as personal utilization. Change detection has been carried on to display the decline in surface water and ground water due to increased concentration of built-up land, siltation of ponds as well as decrease in the number of ponds. The watershed is experiencing large scale anthropogenic activities. The government must curb built-up activities and desilt the ponds to sustain the monsoon water, facilitating more recharge. The results of the study can serve as a basis for planning as well as for the development of a sustainable basin area.
\end{abstract}

\section{Keywords}

Morphometry, Meghadrigedda, GIS, Mandal 


\section{Introduction}

Remote sensing technology has opened up avenues in groundwater prospects exploration and management. Satellite images are increasingly used in ground water exploration because of their utility in identifying various ground water features which may serve as either direct or indirect indicators of the presence of groundwater [1].

Water, the most important natural resource which obviously forms the core of our ecological system on this earth has been abused by the human population over generations.

Around $70 \%$ of India's population is directly or indirectly dependent on agriculture-based economy and availability of water resources is a prerequisite to it. According to a report published by the central water commission (CWC) in 2001 [2] the state of Andhra Pradesh is having a total of 1157 watersheds, out of which 106 are overexploited and 79 are in deteriorating condition. It is understandable that optimal utilization of water resources is a key to the sustenance of the future economy. In this context the importance of water has been recognized and greater emphasis is being laid on its economic use and better management. Spatial data distribution of surface water is a support system for numerous scientific activities, agriculture, Industry etc. The hydrogeomorphology, lineament mapping of the watershed along with evaluation of groundwater prospects in the watershed have been attempted by delineating the study area into nine sub-watersheds and hydrogeomorphology, drainage, drainage density, slope, NDVI and NDWI of the study area has been carried out using Landsat data 2010 and Sentinel data 2020 in ARCGIS 10.0 environment. Good groundwater prospects dominate the area showing moderate to excellent potential.

\section{Review of Literature}

Satellite technology is well established in the field of water resources by eminent authors, studies in Visakhapatnam were carried out for the development and major groundwater resources using multi schematic approach based on remote sensing studies are recommended optimal land utilization and farming techniques in Pendurthi mandal, Visakhapatnam district, Andhra Pradesh India, A Geo spatial approach (2020), [3] Usha Chirala and Bhavana Pedada. NDWI and Hydrogeomorphology in attaining optimization of water resources in Pendurthi mandal, Visakhapatnam District, Andhra Pradesh, India using sentinel data-2, (Usha Chirala and Bhavana Pedada, 2020), [4] Mapping of soil erosion zones of Meghadrigedda catchment, Visakhapatnam, India for Conservation-A geospatial approach, Usha Chirala, et al. (2015), [5] Identification of soil erosion zones with special reference to silt deposition in Meghadrigedda Reservoir, Visakhapatnam, India, a Geo spatial approach, Ph.D Thesis 2014 [6]. Correlation of Geomorphometric parameters for the hydrological Characterization of Meghadrigedda watershed, Visakhapatnam, INDIA-A GIS approach. Usha Chirala, et al., (2012) [7]. Integrated study of Geo spatial information technologies for surface 
runoff estimation in an agricultural watershed, Rao, et al., (2010) [8] on groundwater quality of the Meghadrigedda watershed, on Rao and Narendra (2007), [9] Mapping and evaluation of urban sprawling in the Meghadrigedda watershed in Visakhapatnam metropolitan region Nageswara Rao, K. et al., (2006) [10].

\section{Physiography and Study Area}

The study area lies within the geographic coordinates of $17^{\circ} 47^{\prime} 29.245^{\prime \prime}$ and $17^{\circ} 56^{\prime} 47.611^{\prime \prime}$ Northern latitude and $83^{\circ} 2^{\prime} 6.877^{\prime \prime}$ to $83^{\circ} 16^{\prime} 25.243^{\prime \prime}$ Eastern longitude as show in (Figure 1). A total of 63 villages and 71 hamlets come under nine revenue mandals/subdistricts, namely Sabbavaram, Pendurthi Chodavaram, Anandapuram, Visakhapatnam, Paravada and K. Kotapadu of Visakhapatnam and Kottavalsa of Vizianagaram districts respectively (Table 1).

Meghadrigedda is one of the most prominent river catchments, an east flowing river originating from the eastern ghats, Nandikonda hill. It flows south until Kamparupalem village and takes a southeasterly direction at dolphins nose, Visakhapatnam and thereafter joins the Bay of Bengal draining an area of 220.77 sq.km.

The area enjoys subtropical climate and temperatures ranging from $14^{\circ} \mathrm{C}$ $20^{\circ} \mathrm{C}$ in December and $33^{\circ} \mathrm{C}-42^{\circ} \mathrm{C}$ in May. The average rainfall is $1200 \mathrm{~mm}$ (source: Statistical abstracts, Visakhapatnam District 2011). The area comes under humid to subhumid climatic conditions. With high humidity all year round, sultry summer and reasonable monsoon downpour the area receives rainfall from both southwest and Northeast monsoon, but much of the rainfall occurs as intermittent short showers due to its topography.

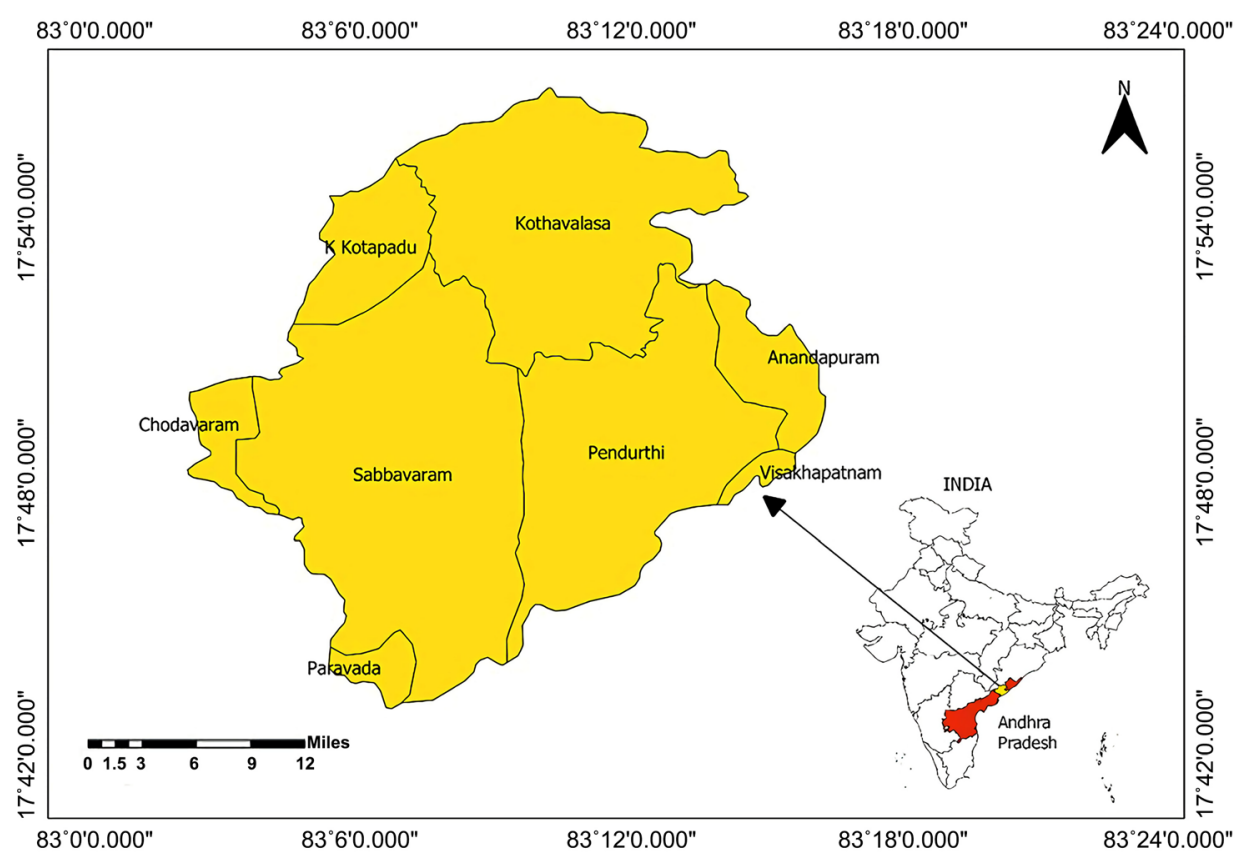

Figure 1. Location of the study area. 
Table 1. Total area covered by the mandals of the study area.

\begin{tabular}{ccc}
\hline S.No. & Mandal Name & Area (in Sq.Km) \\
\hline 1 & Sabbavaram & 133.65 \\
2 & K Kotapadu & 21.69 \\
3 & Kothavalasa & 92.40 \\
4 & Chodavaram & 9.41 \\
5 & Paravada & 5.79 \\
6 & Pendurthi & 84.30 \\
7 & Anandapuram & 16.19 \\
8 & Visakhapatnam & 2.79 \\
& Total & 366 \\
\hline
\end{tabular}

Geologically the area is composed of sedimentary metamorphosed rocks of the Archean system of Precambrian age. The area comes under the Eastern Ghats Mobile belt (EGMB). The strike of the rocks is NNE-SSW. The hill ranges are chiefly grantiferous sillimanite and gneisses (khondalites). These rocks have been intruded by granites, charnockites and dolerites. The area is mostly covered with red and loamy soils together with clay content. The study area is divided into four types of soils-shallow skeletal soils, redloams and clays, gravely loams and clayey soils. As per the 2011 census, the population of the district is 42.88 lakhs with $11.89 \%$ of growth rate and this constitutes $5.06 \%$ of the population of the state while the geographical area is $11,161 \mathrm{~km}^{2}$ which is only $4.1 \%$ of the total area of the state (source: Handbook of statistics, Visakhapatnam District 2011). As per the 2001 census, the total population of the study area is 237,585 (source: Handbook of statistics Visakhapatnam District, 2011).

\section{Aim and Objective}

The delineation of hydrogeomorphological units will help in understanding the composition of the material of the landforms, and identifying more potential groundwater zones which will aid in optimization of the water resources.

\section{Materials and Methods}

Remote sening provides indepth information on the morphological structure and their features which are potential ground water zones. Also, satellite data portrays an unbiased picture of the area providing integrated information on different factors controlling the groundwater regime. Realizing the advantages and the potential of remote sensing technology, for deriving hydrogeomorphological information, it was decided to use the latest available satellite data for hydrogeomorphological maps of Meghadrigedda watershed while adopting visual and digital interpretation technique. Existing geological maps and other collateral data were also used, supplemented by field checks with GPS. The entire study has been divided into prefield, field and post field. Survey of India (SOI) 
$65 \mathrm{O} / 1$ topographical map has been geo-referenced and was used as the base map for the study. The satellite data used in the study is downloaded from the USGS Earth Explorer (EE), the data portal for obtaining the geo-spatial datasets. In this study the Landsat-5 TM satellite image is used for the 2010 data analysis. For 2020 data analysis, the Sentinel-2 Satellite imagery is used. The Sentinel data used in the study is acquired on April 02, 2020, with resolution of $10 \mathrm{~m}$ downloaded from USGS EE. Band- 4 and Band- 8 is used for NDVI analysis and Bands 3 and 8 are used in NDWI analysis. The evaluation of groundwater prospects in the watershed have been attempted by delineating the study area into nine sub-watersheds and hydrogeomorphology, drainage, drainage density, slope, NDVI and NDWI of the study area has been carried out using Landsat data 2010 and Sentinel data 2020 in ARCGIS 10.0 environment. Division of the study area into sub-watersheds, demarcation of the drainage network, demarcated as a vector layer in *shp format, thematic maps and the analysis was all carried out in ARCGIS 10.0 environment. Two spectral indices were used namely NDVI (normalized difference vegetative index) developed by Rousse, et al., in $1973 \mathrm{NDVI}=$ NIR - RED/NIR + RED and NDWI (Normalized difference water Index) developed by Mcfeeters in 1996 NDWI = NIR - SWIR/NIR + SWIR. Index methods are used for surface water estimation as they separate the water from the background based on a particular threshold value. NDVI and NDWI both show better results for only pure water pixels.

\section{Meghadrigedda Reservoir}

The geographic coordinates of the reservoir are East Longitude $83^{\circ} 11^{\prime} 27^{\prime \prime}$ and North Latitude $17^{\circ} 45^{\prime} 54^{\prime \prime}$ respectively. It covers an area of $6.6 \mathrm{sq} . \mathrm{km}$ of the study area, a shallow reservoir constructed across the river Meghadrigedda near Kamparupalem village, Visakhapatnam in the year 1972. It is formed at the confluence of two important rivers Meghadrigredda and Naravagedda to supply drinking water to Visakhapatnam city. The gross capacity of the reservoir at FRL is estimated to be $1169 \mathrm{mcft}$. The dead storage is $1043 \mathrm{mcft}$. The catchment area is influenced by both southwest and northeast monsoons from June to September, and flash floods occur mostly in October and November due to the influence of cyclones in the Bay of Bengal.

\section{Drainage, Drainage Density and Slope}

The drainage demarcation, processing and analysis of the study area has been carried out as a vector layer in ArcGIS 10.0 environment. Stream ordering has been assigned following the rules of Strahler [11] method. Subsequently, morphometric parameters have been computed using standard empirical equations and was carried out in the ArcGIS 10.0. (Figure 2). Drainage density has been discussed and related to many parameters by several Geomorphologists [12] [13] [14] [15] [16].

According to Deju [17] type of " $\mathrm{D}_{\mathrm{d}}$ " of the region can be categorized as poor, (0.5) medium (0.5 - 1.5) and excellent (1.5) (Figure 3). Surface processes are 


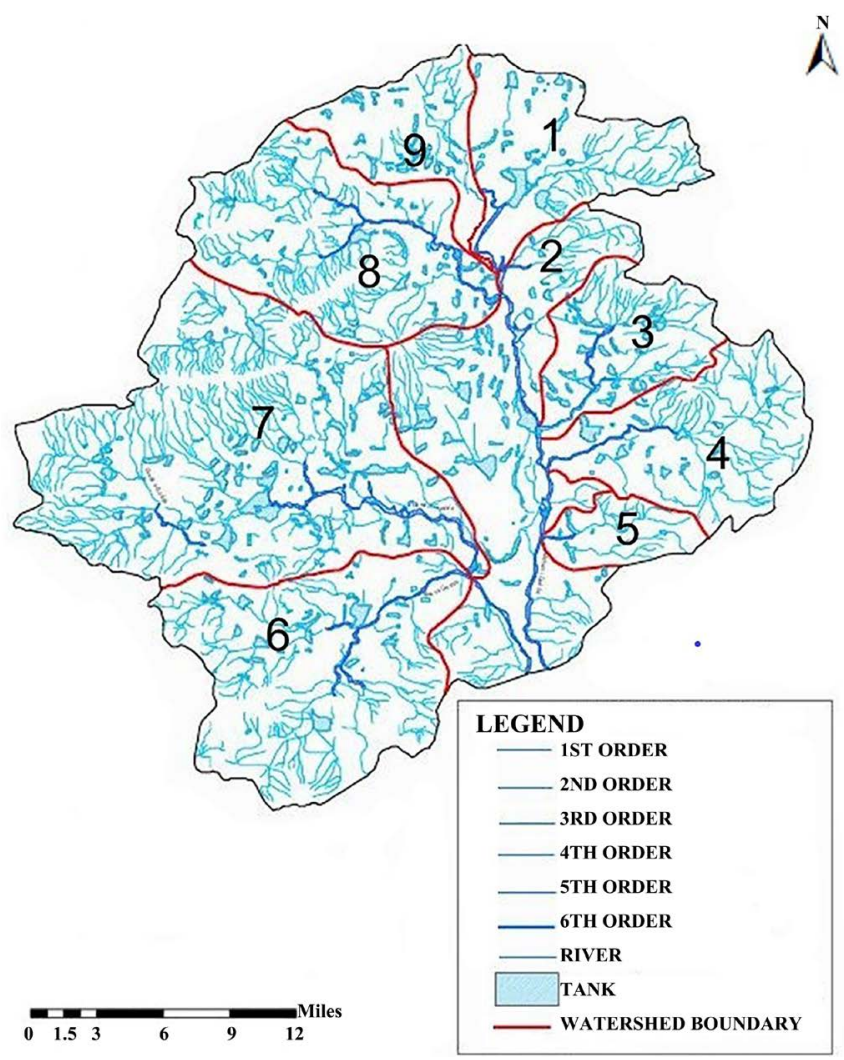

Figure 2. Drainage map of the study area.

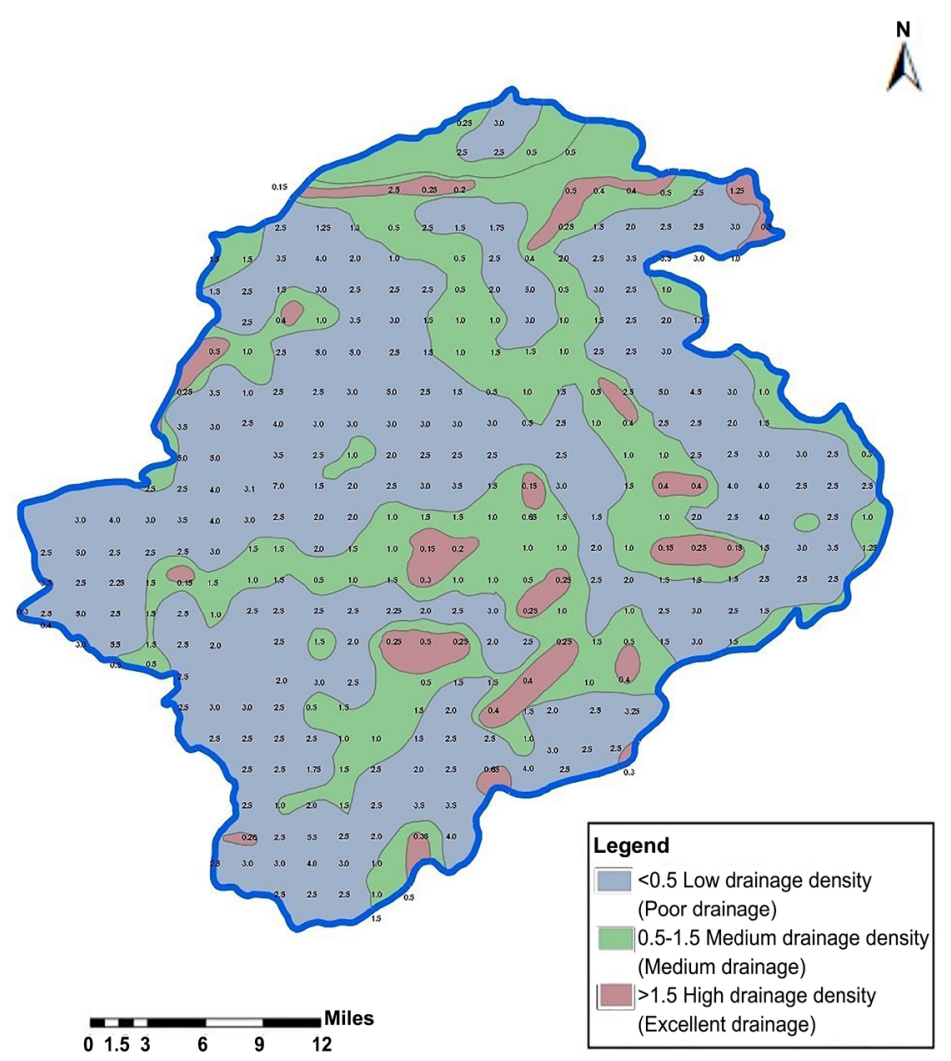

Figure 3. Drainage density of the study area. 
controlled by the lithology and geological structure, which in turn controls the slope form [18] [19], correlated slopes with geomorphology, hydrology and soil erosion.

Slope layers have been delineated with the help of topographical maps. Altogether seven classes have been delineated on the guidelines of National Remote sensing center (NRSC) (Figure 4). Slope percentage has been categorized from $0 \%$ to $35 \%$ area in $\mathrm{km}^{2}$. From the slope analysis it can be deduced the study area is relatively a plain land. The lowest slope category is labeled as one and the highest as seven. The contour interval period is taken as $20 \mathrm{~m}$ interval. The area has six reserved forests mostly distributed in hills namely, Narava Reserved forest, Potukonda reserved forest, Nallkonda reserved forest, Ellappi konda reserved forest, Dabbala and Yerrakonda reserved forest. The Narava reserved forest has slope categories of 4, 6 and 7. The Potukonda reserved forest has categories ranging from 3, 4, 5, 6 and 7. Nallkonda forest also has 3, 4, 5, 6 and 7 categories. Ellappikonda has categories of 6 and 7. Yerrakonda and Dabbala reserved forest has categories of 3,5,6, and 7. All around in the study area there are inselbergs and residual hills with slope categories of 4, 5, 6 and 7.

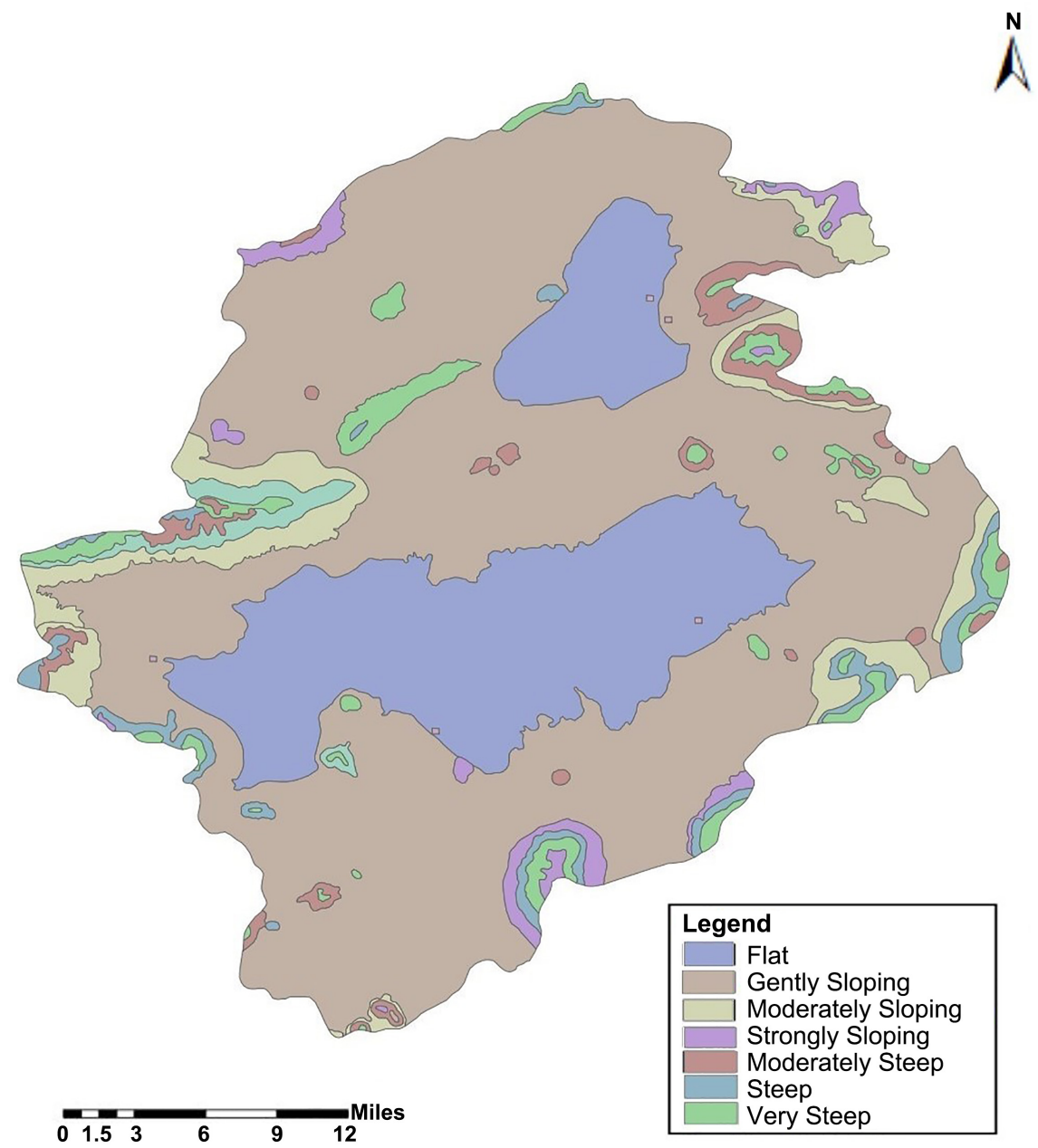

Figure 4. Slope of the study area. 
To the north of the study area is a plain area coming in the category of 1 and 2 , so also in the central area of the study area. The Sabbavaram mandal has 9 villages in the slope category 1 and 10 villages in the slope category 2. Pendurthi mandal has 5 villages in the slope category 1 and 16 villages in the slope category 2. K. Kotapadu has 7 villages which all come under the slope category 2. All the above mentioned come under Visakhapatnam district, whereas only Kottavalsa mandal alone comes under Visakhapatnam district with only 3 villages in slope category 1 and 10 villages in slope category 2, Kottavalsa village is the only village which comes partly under 1 and partly under 2 slope categories. The study area is a relatively plain land. Categories of slope range from 1 to 7 . The contour interval has been taken as $20 \mathrm{~m}$ (Table 2).

\section{Hydrogeomorphic Units}

Hydrogomorphology mapping using remote sensing data has been conventionally used for delineating ground water prospect zones. In complex terrain comprising fluvial, denudational and structural geomorphic units the intricate relationship among various parameters controlling groundwater regimes is difficult to establish, with GIS tool it is very helpful in analyzing quantifying such multivariate aspects of groundwater occurrence [20] [21].

Hydrogeomorphology operates in an interdisciplinary framework focused on the relationship between hydrologic processes with earth materials and the interaction of geomorphic processes relating surface water/groundwater flow regime [22]-[31].

Scheidegger first defined "hydrogeomorphology" as the study of landforms as caused by the action of water. Dunne [32] describes the early progress in hydrogeomorphology, starting with conceptual geomorphic interpretations evolving to quantitative physically based investigations, and finally to modelling studies.

In geomorphic interpretations, eight fluvial classes were identified out of which four are run-off zones and the rest are infiltration zones. Run-off zones contribute to silt into the plains experiencing siltation of many surface water bodies in the study area.

Table 2. Slope pattern in the study area.

\begin{tabular}{cccccc}
\hline S.No & Slope category & $\begin{array}{c}\text { Slope } \\
\text { percentage }\end{array}$ & $\begin{array}{c}\text { Upper and lower limit } \\
\text { of counter spacing }\end{array}$ & Are in Sq.km & $\begin{array}{c}\text { Area in } \\
\text { percentage }\end{array}$ \\
\hline 1 & Flat & $0 \%-1 \%$ & $>4 \mathrm{cms}$ & 89.72 & 24.39 \\
2 & Gently sloping & $1 \%-3 \%$ & $1.33-4 \mathrm{cms}$ & 214.52 & 58.30 \\
3 & Moderately sloping & $3 \%-5 \%$ & $0.8-1.33 \mathrm{cms}$ & 27.92 & 7.59 \\
4 & Strongly sloping & $5 \%-10 \%$ & $0.4-0.8 \mathrm{cms}$ & 6.83 & 1.86 \\
5 & Moderately steep & $10 \%-15 \%$ & $0.25-0.4 \mathrm{cms}$ & 8.48 & 2.30 \\
6 & Steep & $15 \%-35 \%$ & $0.11-0.25 \mathrm{cms}$ & 0.18 & 2.76 \\
7 & Very steep cliff & $>35 \%$ & $<0.11 \mathrm{cms}$ & 10.35 & 2.80 \\
Total & & & & 368.00 & 100.00 \\
\hline
\end{tabular}


The hydrogeomorphological map of the Meghadrigedda watershed is presented in (Figure 5). The map presented in color scheme clearly brings out the various geomorphological units in detail in Table 3. The study area has been demarcated into Structural hills, Residual hills, Inselbergs, Flood plain, Buried Pediplain moderate, Buried Pediplain shallow, Pediment zone and the Pediment. The other striking features in the map are structural hills shown in all around the watershed.

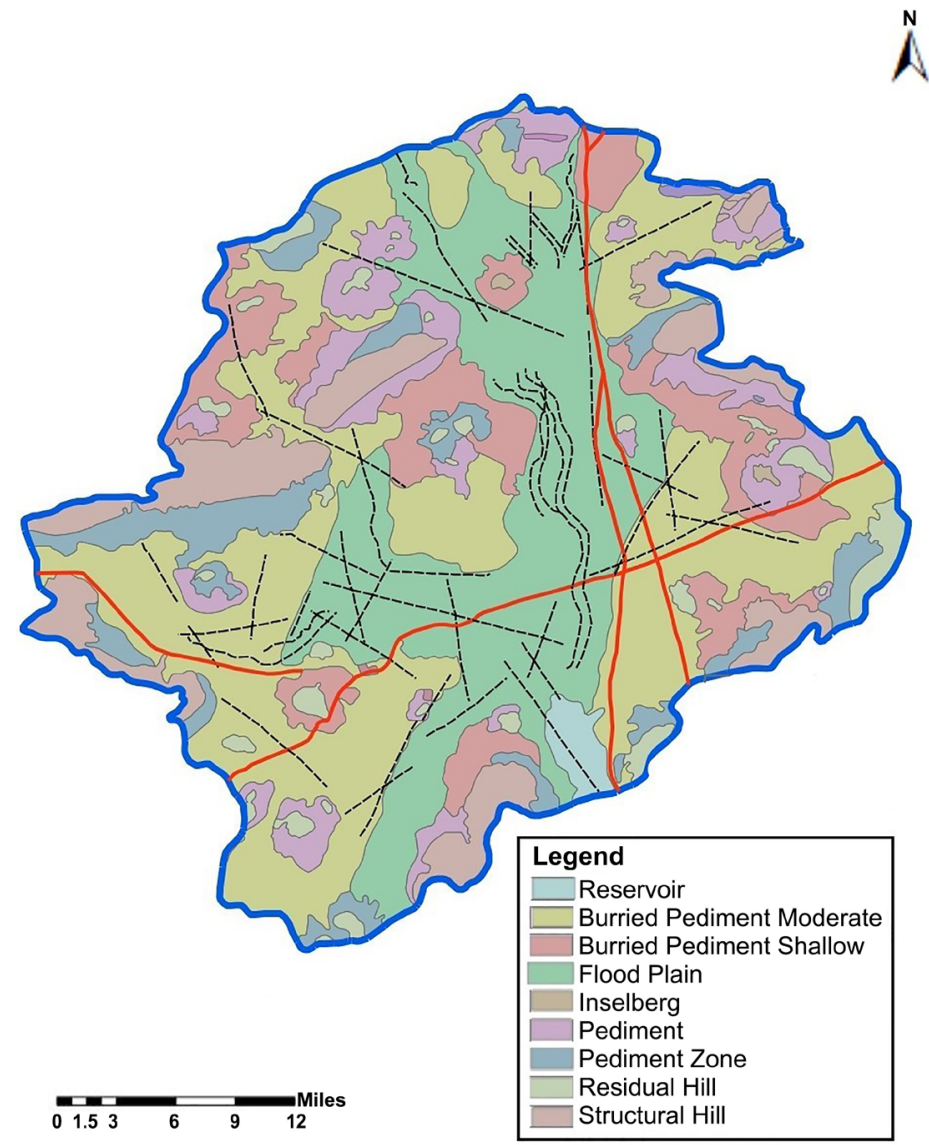

Figure 5. Hydrogeomorphology of the study area.

Table 3. Classification of hydrogeomorphological units.

\begin{tabular}{cccc}
\hline S.No & Category & Area in Sq.km & Area in \% \\
\hline 1 & Structural hills & 41.60 & 11.30 \\
2 & Inselbergs, Residual hills & 37.91 & 10.30 \\
3 & Pediment zone & 0.09 & 0.05 \\
4 & Pediment & 24.37 & 6.89 \\
5 & Buried pediment shallow & 44.22 & 11.74 \\
6 & Buried pediment moderate & 124.52 & 33.83 \\
7 & Flood plain & 93.29 & 25.89 \\
Total & & 366 & 100.00 \\
\hline
\end{tabular}


Table 4. Net area irrigated source wise and mandal wise (in hectares).

\begin{tabular}{ccccccc}
\hline \multirow{2}{*}{ S.No. } & Mandal & $\begin{array}{c}\text { Total no. of } \\
\text { inhabited villages }\end{array}$ & \multicolumn{4}{c}{$\begin{array}{c}\text { No. of villages covered with } \\
\text { major source of drinking water facility }\end{array}$} \\
\cline { 4 - 7 } & & 31 & 26 & 31 & 31 & 0 \\
\hline 1 & Sabbavaram & 23 & 1 & 385 & 15 & 0 \\
2 & Pendurthi & 33 & 27 & 5 & 0 & 0 \\
3 & Anandapuram & 13 & 12 & 0 & 0 & 0 \\
4 & Visakhapatnam (Rural) & 16 & 16 & 16 & 16 & 0 \\
5 & Visakhapatnam (Urban) & 18 & 18 & 18 & 0 & 0 \\
6 & Paravada & 32 & 32 & 32 & 0 & 0 \\
7 & K Kotapadu & 31 & 68 & 1060 & 0 & 0 \\
8 & Chodavaram & & & & & \\
\hline
\end{tabular}

Table 5. Mandal wise irrigation sources.

\begin{tabular}{|c|c|c|c|c|c|c|c|c|c|c|}
\hline \multirow{2}{*}{ S.No. } & \multirow{2}{*}{ Mandal } & \multicolumn{7}{|c|}{ Net area irrigated under } & \multirow{2}{*}{$\begin{array}{l}\text { Area irrigated } \\
\text { more than once }\end{array}$} & \multirow{2}{*}{$\begin{array}{c}\text { Gross area } \\
\text { irrigated }\end{array}$} \\
\hline & & Canals & Tanks & Tube wells & Dug Wells & Lift Irrigation & Other Sources & Total & & \\
\hline 1 & Sabbavaram & 0 & 1361 & 330 & 60 & 0 & 0 & 1751 & 314 & 2065 \\
\hline 2 & Pendurthi & 0 & 124 & 655 & 455 & 0 & 26 & 1260 & 167 & 1427 \\
\hline 3 & Anandapuram & 0 & 403 & 305 & 902 & 0 & 0 & 1610 & 648 & 2258 \\
\hline 4 & Visakhapatnam (Rural) & 0 & 7 & 0 & 13 & 0 & 33 & 53 & 16 & 69 \\
\hline 5 & Visakhapatnam (Urban) & 0 & 0 & 0 & 0 & 0 & 0 & 0 & 0 & 0 \\
\hline 6 & Paravada & 0 & 85 & 127 & 17 & 0 & 0 & 229 & 64 & 293 \\
\hline 7 & K Kotapadu & 1322 & 1462 & 609 & 504 & 0 & 0 & 3897 & 1221 & 5118 \\
\hline 8 & Chodavaram & 3448 & 782 & 1210 & 285 & 65 & 0 & 5790 & 4231 & 10021 \\
\hline
\end{tabular}

${ }^{*}$ Kothavalasa mandal comes under Vizianagaram district.

Table 6. Minor irrigation sources.

\begin{tabular}{ccccc}
\hline S.No. & Mandal & No. of sources & Regd. Ayacut & $\begin{array}{c}\text { Actual area irrigated } \\
\text { (in hectares) }\end{array}$ \\
\hline 1 & Sabbavaram & 256 & 4423 & 4200 \\
2 & Pendurthi & 115 & 1835 & 1835 \\
3 & Anandapuram & 175 & 1939 & 1551 \\
4 & Visakhapatnam (Rural) & 1 & 259 & 0 \\
5 & Visakhapatnam (Urban) & 0 & 0 & 0 \\
6 & Paravada & 205 & 2165 & 410 \\
7 & K Kotapadu & 228 & 3213 & 3051.39 \\
8 & Chodavaram & 75 & 4042 & 3838.52 \\
\hline
\end{tabular}

\section{NDVI and NDWI}

These Indices have been used in many applications, including estimation of crop yields and end-of-season above ground dry biomass [33]. NDVI and NDWI for 
all the nine sub-watersheds has been delineated to ascertain effective planning at village level and to augment the water resources in relation to the prevailing hydrogeomorphological units (Figures 6-9, Table 8, Table 9).

Table 7. Mandal wise area irrigated by sprinklers and drip irrigation (in hectares).

\begin{tabular}{cccccc}
\hline S.No. & Mandal & $\begin{array}{c}\text { No. of sprinklers } \\
\text { working }\end{array}$ & $\begin{array}{c}\text { Area irrigated } \\
\text { (in hectares) }\end{array}$ & $\begin{array}{c}\text { No. of drip } \\
\text { working }\end{array}$ & $\begin{array}{c}\text { Area irrigated } \\
\text { (in hectares) }\end{array}$ \\
\hline 1 & Sabbavaram & 71 & 72.02 & 72 & 64.61 \\
2 & Pendurthi & 15 & 12.47 & 4 & 3.31 \\
3 & Anandapuram & 32 & 38.65 & 58 & 51.6 \\
4 & Visakhapatnam (Rural) & 0 & 0 & 4 & 4.96 \\
5 & Visakhapatnam (Urban) & 0 & 0 & 5 & 2.74 \\
6 & Paravada & 25 & 28.61 & 31 & 19.95 \\
7 & K Kotapadu & 40 & 45.56 & 76 & 57.01 \\
8 & Chodavaram & 41 & 35.67 & 55 & 43.09 \\
\hline
\end{tabular}

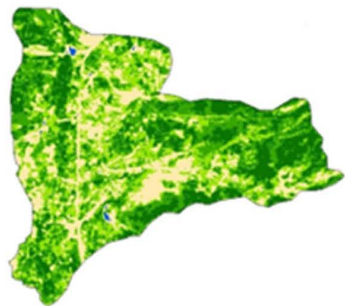

Watershed-1

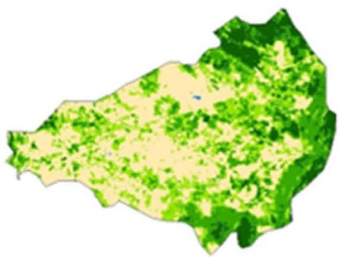

Watershed-4

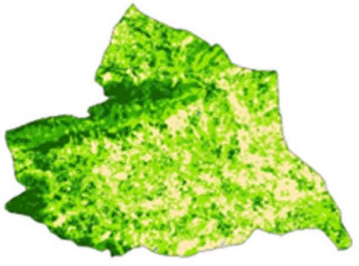

Watershed-7

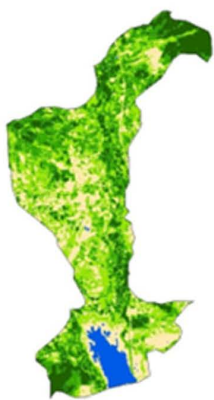

Watershed-2

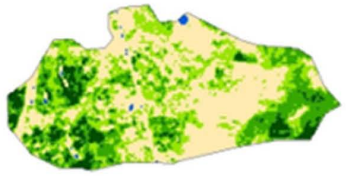

Watershed-5

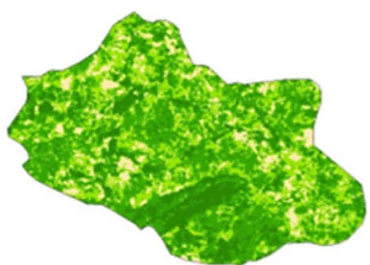

Watershed-8

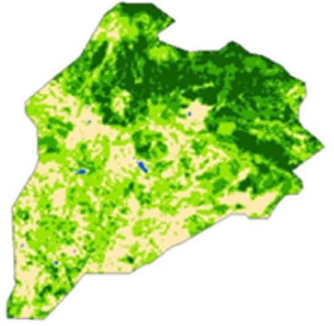

Watershed-3

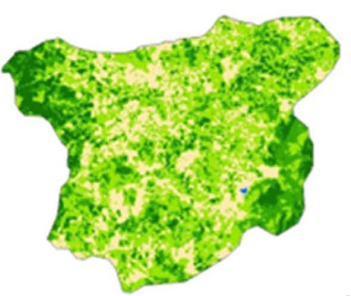

Watershed-6

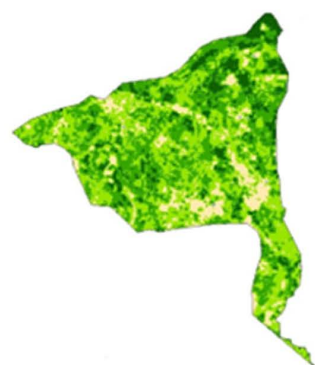

Watershed-9

Figure 6. NDVI maps for the year 2010. 


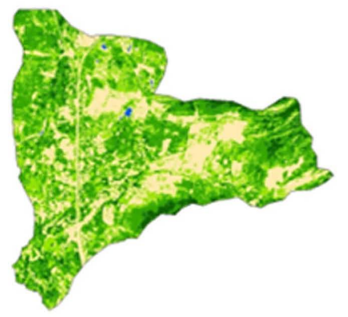

Watershed-1

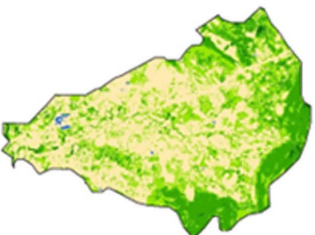

Watershed-4

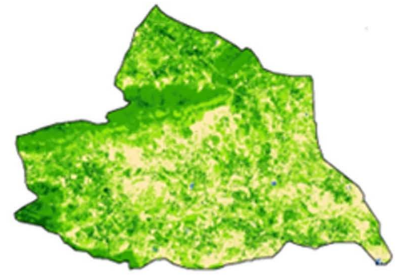

Watershed-7

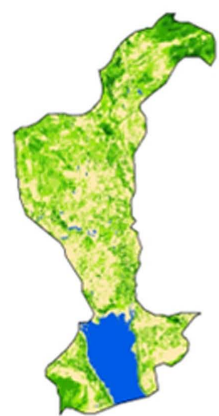

Watershed-2

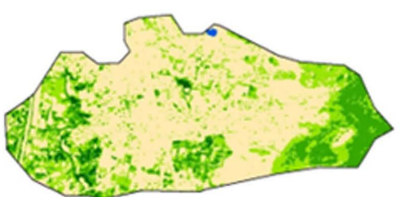

Watershed-5

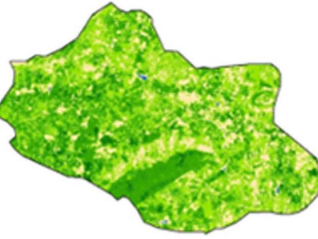

Watershed-8

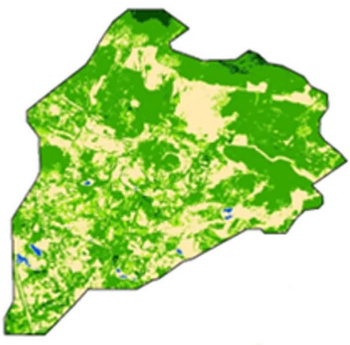

Watershed-3

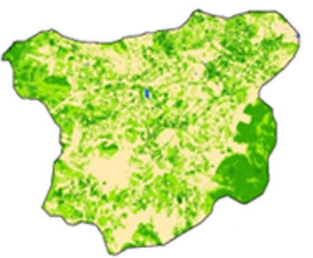

Watershed-6

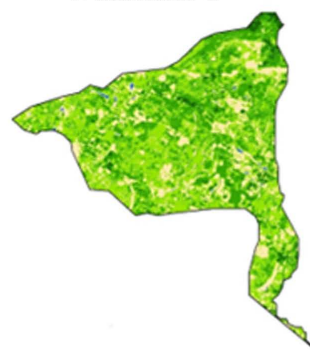

Watershed-9

Legend NDVI Moderate Vegetation Barren and Built-up Water Bodies

Figure 7. NDVI maps for the year 2020.

Table 8. NDVI for the year 2010 and 2020.

\begin{tabular}{lcccccc}
\hline Watershed & NDVI & $\begin{array}{c}\text { Shrubs and } \\
\text { grassland }\end{array}$ & $\begin{array}{c}\text { Moderate } \\
\text { Vegetation }\end{array}$ & $\begin{array}{c}\text { Dense } \\
\text { Vegetation }\end{array}$ & $\begin{array}{c}\text { Barren and } \\
\text { builtup }\end{array}$ & Waterbodies \\
\hline Watershed-1 & 2010 & 0.16 to 0.24 & 0.24 to 0.32 & 0.32 to 0.53 & -0.10 to 0.16 & -0.35 to -0.10 \\
& 2020 & 0.30 to 0.40 & 0.40 to 0.50 & 0.50 to 0.64 & -0.10 to 0.30 & -0.20 to -0.10 \\
Watershed-2 & 2010 & 0.11 to 0.20 & 0.20 to 0.30 & 0.30 to 0.5 & -0.05 to 0.11 & -0.30 to -0.05 \\
& 2020 & 0.30 to 0.40 & 0.40 to 0.50 & 0.50 to 0.67 & 0.00 to 0.30 & -0.17 to 0.00 \\
Watershed-3 & 2010 & 0.17 to 0.27 & 0.27 to 0.35 & 0.35 to 0.50 & 0.00 to 0.17 & -0.31 to 0.00 \\
& 2020 & 0.25 to 0.30 & 0.30 to 0.50 & 0.50 to 0.61 & -0.07 to 0.25 & -0.24 to -0.07 \\
Watershed-4 & 2010 & 0.17 to 0.24 & 0.24 to 0.33 & 0.33 to 0.49 & -0.04 to 0.17 & -0.07 to -0.04 \\
& 2020 & 0.30 to 0.40 & 0.40 to 0.50 & 0.50 to 0.62 & 0.00 to 0.30 & -0.20 to 0.00 \\
Watershed-5 & 2010 & 0.14 to 0.20 & 0.20 to 0.30 & 0.30 to 0.47 & -0.02 to 0.14 & -0.17 to -0.02 \\
& 2020 & 0.30 to 0.40 & 0.40 to 0.50 & 0.50 to 0.65 & -0.06 to 0.30 & -0.10 to -0.06
\end{tabular}




\section{Continued}

\begin{tabular}{llllllll}
\hline \multirow{2}{*}{ Watershed-6 } & 2010 & 0.13 to 0.24 & 0.24 to 0.31 & 0.30 to 0.51 & 0.00 to 0.13 & -0.02 to 0.03 \\
& 2020 & 0.30 to 0.40 & 0.40 to 0.50 & 0.50 to 0.65 & -0.02 to 0.30 & -0.14 to -0.06 \\
Watershed-7 & 2010 & 0.14 to 0.26 & 0.26 to 0.33 & 0.33 to 0.54 & 0.00 to 0.14 & -0.21 to 0.00 \\
& 2020 & 0.30 to 0.40 & 0.40 to 0.50 & 0.50 to 0.65 & 0.00 to 0.30 & -0.17 to 0.00 \\
Watershed-8 & 2010 & 0.12 to 0.20 & 0.20 to 0.30 & 0.30 to 0.49 & 0 to 0.12 & \\
& 2020 & 0.32 to 0.42 & 0.42 to 0.50 & 0.50 to 0.66 & 0.00 to 0.32 & -0.16 to 0.00 \\
Watershed-9 & 2010 & 0.10 to 0.22 & 0.22 to 0.31 & 0.31 to 0.54 & 0.00 to 0.12 & -0.17 to 0.00 \\
& 2020 & 0.32 to 0.42 & 0.42 to 0.50 & 0.50 to 0.65 & 0.00 to 0.32 & -0.15 to 0.00 \\
\hline
\end{tabular}

Table 9. Villages, slope and Hydrogeomorphic units of the watersheds.

\begin{tabular}{|c|c|c|c|}
\hline S.No & Villages & Slope & Hydrogromorphological unit \\
\hline \multicolumn{4}{|c|}{ Area in sq.km 28.26} \\
\hline \multirow[t]{7}{*}{ Watershed 1} & Adunpalem & 2 & Buried pediment moderate \\
\hline & Appandonapalem & 2 & Buried pediment moderate \\
\hline & Aradhanapalem & 2 & Buried pediment moderate \\
\hline & Baligattam & 2 & Buried pediment moderate \\
\hline & Gollapalem & 2 & Buried pediment moderate \\
\hline & Mulgapakavanipalem & 1 & Flood plain \\
\hline & Tumakapalli & 1 & Flood plain \\
\hline \multicolumn{4}{|c|}{ Area in sq.km 58.14} \\
\hline \multirow[t]{16}{*}{ Watershed 2} & Chikkapeta & & Flood plain \\
\hline & Chipruruvalsa & 1 & Flood plain \\
\hline & Chintalaagraharam & 2 & Buried pediment moderate \\
\hline & Dabala & 1 & Flood plain \\
\hline & Denduru & 1 & Flood plain \\
\hline & Gannisettipalem & 1 & Flood plain \\
\hline & Gollalapalem & 1 & Flood plain \\
\hline & Gorapalli & 1 & Flood plain \\
\hline & Gullivadada & & \\
\hline & Jerripotulapalem & 1 & Flood plain \\
\hline & Kottavalsa & 1 & Flood plain \\
\hline & Mindivalsa & 1 & Flood plain \\
\hline & Nandivanipalem & 1 & Flood plain \\
\hline & Narvavanipalem & 2 & Buried pediment moderate \\
\hline & Padmanabhapuram & 2 & Buried pediment moderate \\
\hline & Pendurthi & 1 & Flood plain \\
\hline
\end{tabular}




\section{Continued}

\begin{tabular}{|c|c|c|c|}
\hline & Pinagadi & 1 & Flood plain \\
\hline & Porlupalem & 1 & Flood plain \\
\hline & Ramapuram & 1 & Flood plain \\
\hline & Ramachandrapuram & 1 & Flood plain \\
\hline & Shirmpuram & 1 & Flood plain \\
\hline & Santapalem & 1 & Flood plain \\
\hline \multicolumn{4}{|l|}{ Area in sq.km 21.30} \\
\hline \multirow[t]{5}{*}{ Watershed 3} & Bodunaiydupalem & 4 & Pediment \\
\hline & Desaputrunipalem & 4 & Pediment \\
\hline & Gollepalli & 1 & Floodplain \\
\hline & Mudapaka & 2 & Pediment \\
\hline & Ramavaram & 4 & Pediment \\
\hline Watershed 4 & Bandavanipalem & 2 & Buried pediment moderate \\
\hline \multirow[t]{7}{*}{ Area in sq.km 32.96} & Duvvupalem & 2 & Buried pediment moderate \\
\hline & Gangammapeta & 2 & Buried pediment moderate \\
\hline & Juttada & 2 & Buried pediment moderate \\
\hline & Naravanipalem & 1 & Floodplain \\
\hline & Pulagalipalem & 2 & Buried pediment moderate \\
\hline & Rajjayyapeta & 1 & Floodplain \\
\hline & Valimeraka & 2 & Buried pediment moderate \\
\hline \multicolumn{4}{|l|}{ Area in sq.km 9.16} \\
\hline \multirow[t]{2}{*}{ Watershed 5} & Papayyarajupalem & 2 & Buried pediment moderate \\
\hline & Lakshmipuram & 1 & Floodplain \\
\hline \multicolumn{4}{|l|}{ Area in sq.km 57.31} \\
\hline \multirow[t]{12}{*}{ Watershed 6} & Amrutapuram & 1 & Floodplain \\
\hline & Amarapavanipalem & 1 & Floodplain \\
\hline & Appayapalem & 1 & Floodplain \\
\hline & Erakunaidupalem & 2 & Buried pediment moderate \\
\hline & Gaannvanipalem & 2 & Buried pediment moderate \\
\hline & Gollalapalem & 1 & Floodplain \\
\hline & Irruwada & 1 & Floodplain \\
\hline & Ippillivanipalem & 1 & Floodplain \\
\hline & Jaganthpuram & 2 & Buried pediment moderate \\
\hline & Mushiwada & 2 & Buried pediment moderate \\
\hline & Nangivanipalem & 1 & Floodplain \\
\hline & Nanginadipadu & 3 & Pediment shallow \\
\hline
\end{tabular}




\section{Continued}

\begin{tabular}{ccc}
\hline Paidwada & 2 & Buried pediment moderate \\
Pitapalem & 2 & Buried pediment moderate \\
Sakepalli & 2 & Buried pediment moderate \\
Settivanipalem & 3 & Pediment shallow \\
Tammayapalem & 1 & Floodplain \\
\hline
\end{tabular}

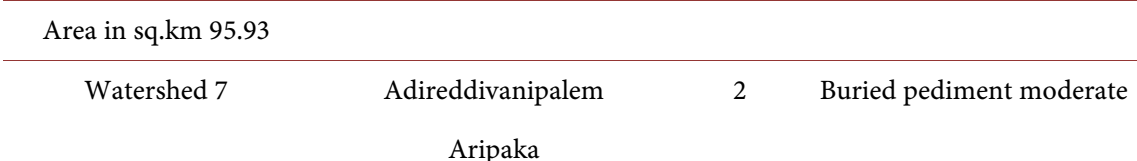

Amarapinivanipalem

Antakapalli

Boduvalasa

Chandrayanapeta

Chinnayyapalem

Chinna ratapalem

Chinna yangali

Duddwaka

Ellappi

Galibhimavaram

Gotivada

Gullepalli

Jangalapalem

Killivanipalem

Laggisettipalem

Mallunaiydupalem

Mallapalli

Nakkavaipalem

Pallavanipalem

Patasabbavaram

Peddavangali

Rayulammapalem

Rayapura agraharam

Sabaavaram

Saripalli

Tekkalipalem

Telukulapalem

Ummanivanipalem

Yatapalem
2

Buried pediment moderate

Buried pediment moderate

2

2

3

2

1

2

1

2

1 (1)

2

Buried pediment moderate

2

2

2

4

2

Floodplain

Buried pediment moderate

Buried pediment moderate

Buried pediment moderate

Buried pediment moderate Pediplain shallow

Buried pediment moderate

Buried pediment moderate

Floodplain

Buried pediment moderate

Floodplain

Buried pediment moderate

Floodplain

Buried pediment moderate

Buried pediment moderate

Buried pediment moderate

Floodplain

Buried pediment moderate

Buried pediment moderate

Pediment

Buried pediment moderate

Buried pediment moderate

Area in sq.km 45.70

2 Buried pediment moderate 


\section{Continued}

\begin{tabular}{cccc}
\hline Watershed 8 & 2 & Buried pediment moderate \\
Kottavanipalem & 2 & Buried pediment moderate \\
Mallapalli & 2 & Buried pediment moderate \\
Patavalsa & 4 & Pediment \\
Ramalingapuram & 2 & Buried pediment moderate \\
Santapalem & 3 & Pediplain shallow \\
Srungavaram & 2 & Buried pediment moderate \\
Surea in sq.km 17.59 & Sudhivalsa & 4 & Pediment \\
\hline Watershed 9 & Devada & 1 & Floodplain \\
& Narapam & 1 & Floodplain \\
& Nimmanapalem & 1 & Floodplain \\
& Viyyampeta & 1 & Floodplain \\
\hline
\end{tabular}

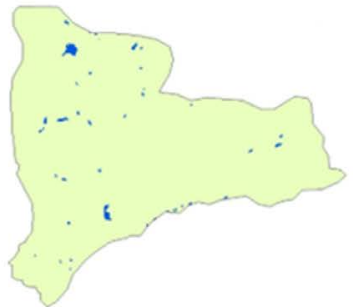

Watershed-1

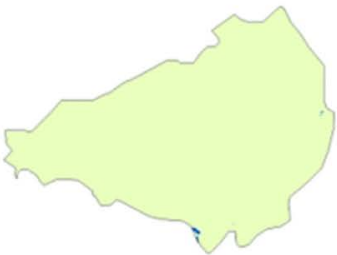

Watershed-4

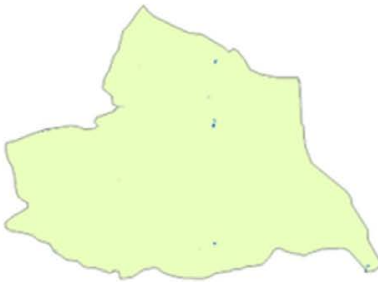

Watershed-7

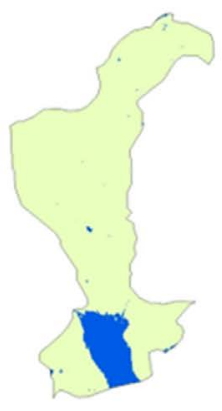

Watershed-2

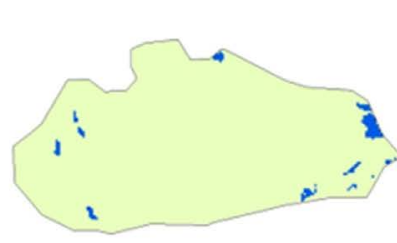

Watershed-5

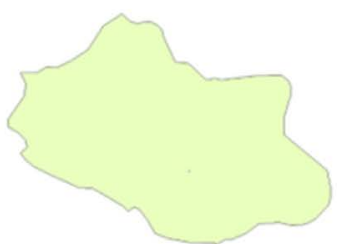

Watershed-8

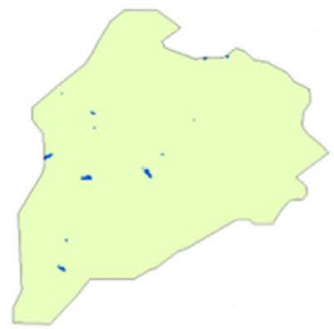

Watershed-3

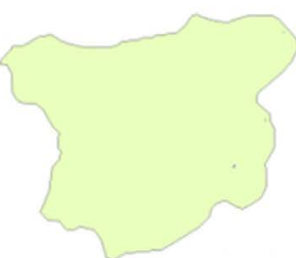

Watershed-6

Figure 8. NDWI maps for the year 2010. 


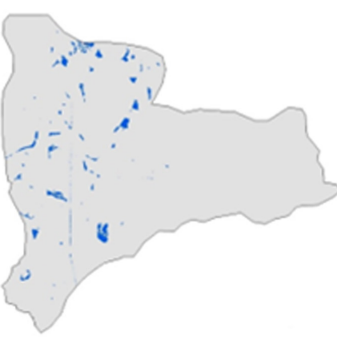

Watershed-1

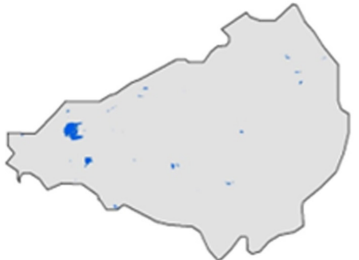

Watershed-4

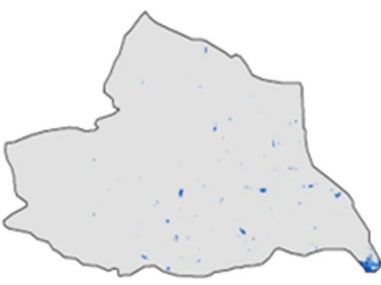

Watershed-7

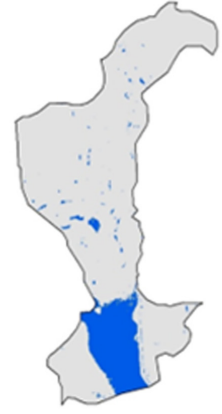

Watershed-2

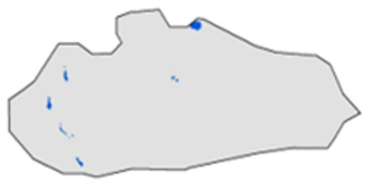

Watershed-5

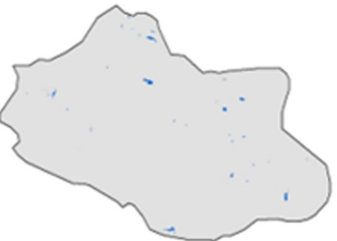

Watershed-8

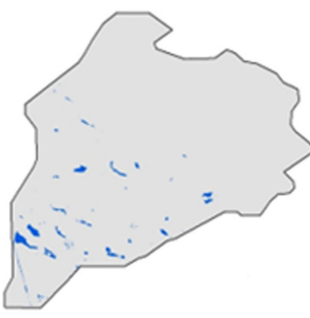

Watershed-3

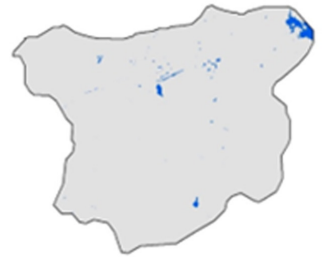

Watershed-6

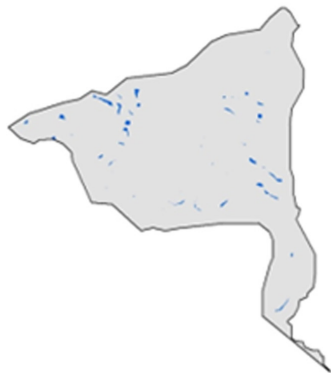

Watershed-9

Figure 9. NDWI maps for the year 2020.

\subsection{Descripition of the Watersheds}

\subsubsection{Watershed 1}

This watershed has isolated hillocks of Quartzite and migmatite type of rocks. Dendritic drainage pattern are prominently seen in khondalite hillocks and plains. It has moderate slopes with perennial tanks. The watershed is covered with buried pediplain moderate and flood plain highly conducive for groundwater and the vegetation content as well as water levels are conducive.

\subsubsection{Watershed 2}

It is characterized by highly denuded khondalite rocks with rolling topography characterized by sub-dendritic drainage and discontinuous with sparse moderate slopes, especially noticeable around the reservoir. It is mostly seen along the flood plain of the river, hence very fertile, and it is supported by another hydro- 
geomorphic unit, buried pediplain moderate which is also good conduit to ground water.

\subsubsection{Watershed 3}

It is characterized with low slopes, perennial tanks and moderate storage capacity is observed. Prevalence of khondalite rocks and predominant lineaments. Hdrogeomorphically this watershed is a not good conduit of groundwater as it is covered with pediment. But it has reasonable water source from tanks.

\subsubsection{Watershed 4}

A very good source of ground water falling into the buried pediplain moderate hydrogeomorphic unit, radial, dendritic and sub-dendritic patterns are observed with prevailing khondalite rock with rolling topography. This watershed is good conduit to ground water.

\subsubsection{Watershed 5}

It has only few villages under its domain, and is a good source of ground water with prevailing buried pediplain moderate and flood plain.

\subsubsection{Watershed 6}

A highly conducive unit for groundwater with preponderance of flood plain and buried pediplain moderate. This watershed has main flow of Naravagedda river, a tributary of Meghadrigedda with preponderance of khondalite and quartzite.

\subsubsection{Watershed 7}

The basin being the drainage for the river Naravagedda is a highly conducive ground water unit hydrogeomorphologically categorized in buried pediplain moderate and flood plain. It has very steep slopes with predominance of rill erosion. Khondalite and migamatite cover the drainage basin. A very giant water source, it has many tributaries draining through the watershed. Home to close to 32 villages, an absolute store house of ground water.

\subsubsection{Watershed 8}

Adjoining watershed 7, it is located in the upper catchment, not so a good source of ground water with preponderance of buried pediplain shallow consisting of khondalites and Migamites. The overall watershed has a moderate slope with dendritic drainage apart from other different types of drainage.

\subsubsection{Watershed 9}

This subbasin is the origin of the river meghadrigedda. This unit falls completely under the category of flood plain, but built-up activity has come up tresspassing the flow of water. All the villages are in flood plain with varying types of drainage with prevalence of khondalites. This entire watershed is in floodplain which was once upon a very fertile land for cultivation and huge reserves of water tanks/ponds. Due to the national highway development, there has been a marked increase in linear settlements and conversion of cultivable land to built up land. 


\section{Conclusions}

Hydrogeomorphology, NDVI and NDWI are strongly interconnected. Drainage, drainage density hydrogeomorphology, groundwater prospects maps have been prepared to show that this entire catchment is highly enriched with ground water prospects (Tables 4-7). NDVI has been prepared to show that a once high vegetative cover is being destroyed which is affecting evapotranspiration and other related issues, which can be seen in all the sub-watersheds. There is a marked decrease in vegetation in all the sub-watersheds from 2010 to 2020.

NDWI has been prepared to show that nature is pouring water, but we are misusing the resource. Good vegetation grows where there is plenty of water and abundance of ground water prevails where there is percolation of water which is seen in flood plain and buried pediplan moderate as good conduits of ground water. With the prevailing population explosion and the catchment dependence on ground water for irrigation and drinking, settlements must not be entertained in the areas that are good percolation tanks for water bodies, tube wells and bore wells. Around the flood plain area of the catchment, in Watershed No. 2 huge agglomerations have come up blocking percolation of water which is giving way to surface run-off and eventually heading to sea, leaving the fields and lands dry, which will in turn affect the vegetation, water for storage in ponds and irrigation as well. Ponds are disappearing as well, which are important containers of reserved water. NDWI for the year 2020 in all the watersheds is displaying plenty of water compared to 2010, which is the result of the thunderous outbursts of the long south-west monsoon that we experienced in 2020. Since the reservoir has reached the dead storage, three flood gates were opened to let off water into the sea. Due to a smaller number of ponds around the catchment, the water could not be stored as well in this latest monsoon of 2020 .

There are close to 500 tanks, most of them have silted up, some of the tanks have disappeared as well due to increased construction activity or soil quarrying from the ponds. The tanks must be desilted to increase their storage capacity in the coming monsoon.

The government must take serious measures to curb contracts for housing plots that are destroying arable land which is good for cultivation and water storage, to their profit margin curtailing the nature course and leading to water scarcity. If at all building development is inevitable due to population explosion, Govt must encourage vertical growth of housing in barren areas and save the enriched water storage units.

\section{Acknowledgements}

The authors wish to thank USGS earth explorer for providing the satellite data of LANDSAT 2010 and Sentinel 2020.

\section{Conflicts of Interest}

The authors declare no conflicts of interest regarding the publication of this paper. 


\section{References}

[1] Bahuguna, I.M., Nayak, S., Tamilarsan, V. and Moses, J. (2003) Ground Water Prospects Zones in Basaltic Terrain Using Remote Sensing. Journal Indian Society Remote Sensing, 31, 101-105. https://doi.org/10.1007/BF03030777

[2] Central Water Commission (2001) Water Resources of India, Introduction. GreenFacts, New Delhi.

https://www.greenfacts.org/en/water-resources/1-2/1-pressures-on-ressources.htm\# $\underline{0}$

[3] Chirala, U. and Pedada, B. (2020) Recommended Optimum Land Utilization and Farming Techniques (ROLUFS): A Case Study Pendurthi Mandal, Vishakhapatnam District, Andhra Pradesh India. Energy and Earth Science, 3, 139-170. https://doi.org/10.22158/ees.v3n2p139

[4] Chirala, U. (2020) An Illustrated Study on Mapping of Soil Erosion Zones of Meghadrigedda Catchment, Visakhapatnam, India for Conservation-A Geospatial Approach.

[5] Chirala, U., et al. (2015) Mapping of Soil Erosion Zones of Meghadrigedda Catchment, Vishakhapatnam India for Conservation-A Geospatial Approach. International Journal of Geosciences, 6, 326-338. https://doi.org/10.4236/ijg.2015.64026

[6] Chirala, U. (2014) Identification of Soil Erosion Zones with Special Reference to Silt Deposition in Meghadrigedda Reservoir, Vishakhapatnam, India. A Geo Spatial Approach. Ph.D Thesis.

[7] Chirala, U., et al. (2012) Correlation of Geomorphometric Parameters for the Hydrological Characterization of Meghadrigedda Watershed, Vishakhapatnam, INDIA-A GIS Approach. International Journal of Engineering, Science and Technology, 4, 91-105.

[8] Nageswara Rao, K. and Narendra, K. (2006) Mapping and Evaluation of Urban Sprawling in the Mehadrigedda Watershed in Visakhapatnam Metropolitan Region Using Remote Sensing and GIS. Current Science, 91, 1552-1557.

[9] Narendra, K. and Nageswara Rao, K. (2006) Morphometry of the Meghadrigedda Watershed, Visakhapatnam District, Andhra Pradesh Using GIS and Resourcesat Data. Journal of the Indian Society of Remote Sensing, 34, Article No. 101. https://doi.org/10.1007/BF02991815

[10] Nageswara Rao, K., Narendra, K. and Venkateswarlu, P. (2008) Assessment of Groundwater Quality in Mehadrigedda Watershed, Visakhapatnam District, Andhra Pradesh, India: GIS Approach. Pollution Research, 26, 313-324.

[11] Strahler, A.N. (1964) Quantitative Geomorphology of Drainage Basins and Channel Networks, Section 4-II. In: Chow, V.T., Ed., Handbook of applied Hydrology, Mc Graw-Hill, New York, 4-39.

[12] Chorley, R.J. (1957) Climate and Morphometry. The Journal of Geology, 65, 628-638. https://doi.org/10.1086/626468

[13] Chorley, R.J. (1957) Illustrating the laws of Morphometry. Geological Magazine, 94, 140-150. https://doi.org/10.1017/S0016756800068412

[14] Chorley, R.J. (1969) The Drainage Basin as the Fundamental Geomorphic Unit. In: Chorley, R.J., Ed., Introduction to Physical Hydrology, Routledge, London, 77-99.

[15] Morisawa, M.E. (1962) Quantitative Geomorphology of Some Watersheds in the Appalachian Plateau. GSA Bulletin, 73, 1025-1046. https://doi.org/10.1130/0016-7606(1962)73[1025:QGOSWI]2.0.CO;2

[16] Scheidegger, A.E. (1972) Hydrogeomorphology. Journal of Hydrology, 20, 193-215. https://doi.org/10.1016/0022-1694(73)90061-9 
[17] Deju, A.R. (1971) Regional Hydrology Fundamentals. Gordon \& Breach, Boca Raton, $204 \mathrm{p}$.

[18] Horton, R.E. (1945) Erosional Development of Streams and Their Drainage Basins: Hydro Physical Approach to Quantitative Morphology. Bull of the Geophysical Society of America, 56, 275-370. https://doi.org/10.1130/0016-7606(1945)56[275:EDOSAT]2.0.CO;2

[19] Young, A. (1972) Slopes. Longman, London, 268 p.

[20] Melton, M.A. (1958) Correlation Structure of Morphometric Properties of Drainage Systems and Their Controlling Agents. The Journal of Geology, 66, 442-460.

[21] Carver, S. (1991) Integrating Mutil-Croteria Evaluation with Geographic Information System. International Journal of Geographical Information Systems, 5, 321-339. https://doi.org/10.1080/02693799108927858

[22] Babar, M. (2005) Hydrogeomorphology: Fundamentals, Applications and Techniques. New India Publishing Agency, New Delhi, 274.

[23] Okunishi, K. (1991) Hydrogeomorphological Interactions: A Review of Approach and Strategy. Transactions, Japanese Geomorphological Union, 12, 99-116.

[24] Organization Global Groundwater Resources and Management. Selected Papers from the 33rd International Geological Congress, General Symposium: Hydrogeology, Oslo, Norway, 227-249.

[25] Smith, KG. (1950) Standards for Grading Textures of Erosional Topography. American Journal of Science, 248, 665-668. https://doi.org/10.2475/ajs.248.9.655

[26] Sidle, R.C. and Onda, Y. (2004) Hydrogeomorphology: Overview of an Emerging Science. Hydrological Processes, 18, 597-602. https://doi.org/10.1002/hyp.1360

[27] Schumm, S.A. (1977) The Fluvial System. Wiley, New York.

[28] Johnson, S.L., Swanson, F.J., Grant, G.E. and Wondzell, S.M. (2000) Riparian Forest Disturbances by a Mountain Flood-The Influence of Floated Wood. Hydrological Processes, 14, 3031-3050.

https://doi.org/10.1002/1099-1085(200011/12)14:16/17\%3C3031::AID-HYP133\%3E $\underline{3.0 . \mathrm{CO} ; 2-6}$

[29] Bisson, R.A. and Lehr, J.H. (2004) Modern Groundwater Exploration: Discovering New Water Resources in Consolidated Rocks Using Innovative Hydrogeologic Concepts, Exploration, Drilling, Aquifer Testing and Management Methods. John Wiley \& Sons, Hoboken, 309. https://doi.org/10.1002/0471660833

[30] Goyal, S., Bharadwaj, R.S. and Jugran, D.K. (1999) Multicriterria Analysis Using GIS for Groundwater Resiurces Evlaution in Rawasen and Pili Watershed. U.P. Proc. MapIndia 99, New Delhi.

[31] Das, S., Behra, S.C., Kar, A., Narendra, P. and Guha, N.S. (1997) Hydrogromorphological Mapping in Groundwater Exploration Using Remotely Sensed Data-A Case Study of Keonjhar District in Orissa. Jour of India Society of Remote Sensing, 25, 247-259. https://doi.org/10.1007/BF03019366

[32] Dunne, T (1994) Hydrogeomorphology: An Introduction. Transactions, Japanese Geomorphological Union, 15A, 1-4.

[33] Teixeira, J. (2011) Hidrogeomorfologia e sustentabilidade de recursos hi'dricos subterra^neos. unpublished PhD Thesis, Aveiro University, Aveiro, 504. 